\title{
TTR
}

Traduction, terminologie, rédaction

\section{Whose America? Decolonial Translation by Frederick Douglass and Caetano Veloso}

\author{
Joshua M. Price
}

Volume 28, numéro 1-2, 1er semestre-2e semestre 2015

Territoires, histoires, mémoires

Territories, histories, memories

URI : https://id.erudit.org/iderudit/1041650ar

DOI : https://doi.org/10.7202/1041650ar

Aller au sommaire du numéro

\section{Éditeur(s)}

Association canadienne de traductologie

ISSN

0835-8443 (imprimé)

1708-2188 (numérique)

Découvrir la revue

Citer cet article

Price, J. M. (2015). Whose America? Decolonial Translation by Frederick Douglass and Caetano Veloso. TTR, 28(1-2), 65-89.

https://doi.org/10.7202/1041650ar

\section{Résumé de l'article}

La domination coloniale implique une lutte d'interprétations. Les colonisateurs établissent quelle version de la réalité sera codifiée et deviendra dominante. Rompre avec ce récit dominant et officialisé comporte une lutte contre l'hégémonie. Traducteurs et interprètes subalternes ont souvent servi d'agents des colonisateurs. Cependant, ils contestent souvent les significations dominantes. Ils renversent les significations dominantes, car ils les transforment à travers la division coloniale. Théorisant les pratiques de la traduction de ce point de conjonction ou de contact colonial, cet article s'appuie sur deux exemples pour montrer l'utilité d'une méthodologie décoloniale pour éclairer la façon dont, entre les mains d'un traducteur astucieux, la traduction peut offrir un contre-discours qui déconstruit les systèmes coloniaux de sens. Les deux exemples sont la traduction intralinguale de Frederick Douglass de la signification de « the Fourth of July » (1852) et l'enregistrement par le chanteur Caetano Veloso de la traduction de Augusto de Campos de l'oeuvre de John Donne " Elegy 19: To His Mistress Going To Bed " (1654). Trois caractéristiques interreliées rendent une traduction décoloniale : 1) la traduction est abusive (Lewis, 2000; Venuti, 2013); 2) la langue ou la culture cible est un monde imaginaire, meilleur et plus juste que le monde dans lequel nous vivons (Santos, 2014); 3) la traduction est performative, dans la mesure où elle commence à donner vie à ce monde imaginaire par la performance de la traduction (Austin, 1975). Comme une étreinte déconstructive, ce genre de traduction met en lumière l'héritage colonial et le contexte colonial, voire le genre lui-même, c'est-à-dire son appropriation sélective (Spivak, 1995, p. 31).
Ce document est protégé par la loi sur le droit d'auteur. L’utilisation des services d’Érudit (y compris la reproduction) est assujettie à sa politique d'utilisation que vous pouvez consulter en ligne.

https://apropos.erudit.org/fr/usagers/politique-dutilisation/ 


\title{
Whose America? Decolonial Translation by Frederick Douglass and Caetano Veloso
}

\author{
Joshua M. Price \\ Binghamton University
}

\begin{abstract}
Colonial domination entails a struggle over interpretation. The colonizers establish whose version of reality will be codified and become the dominant one. Breaking with that dominant, authorized account implies a struggle against hegemony. Translators have always played key roles in colonization as agents of the colonizer. Subaltern translators and interpreters have often served in this role. But they often contest dominant meanings. They subvert dominant meanings as they transform them across the colonial divide. Theorizing translation practices from that point of colonial conjunction or contact, this essay adduces two examples to see how a decolonial methodology to study translation and power can shed light on how, in the hands of an astute translator, a translation can offer a counter-narrative that deconstructs colonial systems of meaning. The two examples: Frederick Douglass' intralingual translation of the meaning of the Fourth of July (1852) and singer Caetano Veloso's recording of Augusto de Campos' translation (1979) of John Donne's "Elegy 19: To His Mistress Going To Bed" (1654). Three interconnected characteristics make the translations decolonial. (1) They are abusive (Lewis, 2000; Venuti, 2013). (2) The target language or culture is an imagined world, better and more just than the world we live in now (Santos, 2014). (3) They are performatives insofar as they begin to bring that imagined world into existence through performing the translation (Austin, 1975). As a deconstructive embrace, this kind of translation draws attention to the colonial legacy and to the colonial context, and also to itself- that is, to its own selective appropriation (Spivak, 1995, p. 31).
\end{abstract}

Keywords: translation, colonialism, slave narratives, subaltern studies, decolonial

\section{Résumé}

La domination coloniale implique une lutte d'interprétations. Les colonisateurs établissent quelle version de la réalité sera codifiée et deviendra dominante. Rompre avec ce récit dominant et officialisé comporte une lutte contre l'hégémonie. Traducteurs et interprètes subalternes ont souvent servi d'agents des colonisateurs. Cependant, ils contestent souvent les significations dominantes. Ils renversent les significations dominantes, car 
ils les transforment à travers la division coloniale. Théorisant les pratiques de la traduction de ce point de conjonction ou de contact colonial, cet article s'appuie sur deux exemples pour montrer l'utilité d'une méthodologie décoloniale pour éclairer la façon dont, entre les mains d'un traducteur astucieux, la traduction peut offrir un contre-discours qui déconstruit les systèmes coloniaux de sens. Les deux exemples sont la traduction intralinguale de Frederick Douglass de la signification de «the Fourth of July» (1852) et l'enregistrement par le chanteur Caetano Veloso de la traduction de Augusto de Campos de l'œuvre de John Donne «Elegy 19: To His Mistress Going To Bed» (1654). Trois caractéristiques interreliées rendent une traduction décoloniale: 1) la traduction est abusive (Lewis, 2000; Venuti, 2013); 2) la langue ou la culture cible est un monde imaginaire, meilleur et plus juste que le monde dans lequel nous vivons (Santos, 2014); 3) la traduction est performative, dans la mesure où elle commence à donner vie à ce monde imaginaire par la performance de la traduction (Austin, 1975). Comme une étreinte déconstructive, ce genre de traduction met en lumière l'héritage colonial et le contexte colonial, voire le genre lui-même, c'est-à-dire son appropriation sélective (Spivak, 1995, p. 31).

Mots-clés : traduction, colonialisme, discours d'esclavage, études subalternes, décolonial

\section{Translation and the Colonial Divide}

"Somos más americanos" [We are more American] sing Los Tigres del Norte, a well-known Norteño band of Mexican origin (2006). Who counts as American? Who has the right to that name? In the case of the U.S.-Mexican border, this question is one of open contention. "Somos más americanos que el hijo del anglosajón," sing Los Tigres [We are more American than the children of the Anglo-Saxons]. As Mexicans, they are indigenous to the land- "Yo soy la sangre del indio" [I am the Indian blood]. In an allusion to the formation of the United States, they sing, "Quiero recordarle al gringo: Yo no cruce la frontera, la frontera me cruzó." [I want to remind the gringo that I did not cross the border, the border crossed me. $]^{1}$

Most Mexicans-most Latin Americans, most Spanish speakers-will recognize this song as a reply to the appropriation of the name and identity of "American" ("Americano") by Anglo-

1. The Tigres refer to the Treaty of Guadalupe Hidalgo (1848) by which the Mexican government ceded a large stretch of land to the United States (parts of what would become California, New Mexico, Arizona, Utah, Nevada, Colorado and Texas. Overnight, all the Mexicans and indigenous people who inhabited that land were living in the United States. The border crossed them. 
Americans in the United States and a challenge to how AngloAmericans seek to dispossess others. As heirs to a settler-colony, Anglos in the United States feel they are entitled to the land and to sole control of the name. "Ya me gritaron mil veces que me regrese a mi tierra." [They've shouted at me a thousand times, 'Go back to your country!] No, the Tigres respond, we are all Americans: Chicanx, Mexicanx, Latinx, and, by extension, all who inhabit this continent, from Tierra del Fuego up to Nunavut. Not just the gringos.

Los Tigres translate "American" subversively. Subaltern bards, they destabilize its dominant meaning as they transform American/ Americano across the divide from the colonizers to the colonized. Los Tigres infuse "America/América" (the word, the concept, the geographic region) with expanded meanings, unbound by the artificial lines created by national frontiers. Recasting "Americano" is the source of the poignancy of the song at the point of translation, colonial racism, xenophobia, and the reappropriation of meaning. They play on and broaden the hegemonic meaning of who is American as they project a better future, or better futures, and a more inclusive America.

In the hands of an astute translator, a translation can offer just this kind of counter-narrative that deconstructs colonial systems of meaning. What such a translation can do is catch everyday, unremarkable, ostensibly benign practices as implicated in, and presupposing, the colonial venture. In this case, the translation shows that to affirm "I am an American," in English is to affirm a settler colonial identity. Theorizing translation practices from that point of colonial conjunction or contact, this article takes two examples to see how a decolonial methodology to study translation and power can shed light on a colonial present and these imagined futures.

The two examples: Frederick Douglass' intralingual translation of the meaning of the Fourth of July (1852) and Caetano Veloso's beautiful recording of Augusto de Campos' translation of John Donne's "Elegy 19: To His Mistress Going To Bed” (1654). Each example moves in the opposite direction from the other. Douglass takes a beloved national holiday in the United States and "translates" its meaning to expose its hypocrisy. Veloso takes a frank expression of patriarchal lust that uses colonization as a metaphor for male sexual conquest and makes it a love song to a continent. Both freeze and invert meanings. 


\section{Colonization and the Conquest of Meaning}

A set of questions, adopted from Mary Louise Pratt's Under Imperial Eyes, motivates the need for a decolonial methodology for translation.
*What strategies of representation do European and Euro- American subjects use to affirm their innocence even while they celebrate their colonial legacy?
*How have colonial subjects responded to these representations? How do they appropriate them?
*What materials can one study to answer these questions? (Pratt, 2008, p. 8)

A decolonial methodology of translating would reveal the strategies, would appropriate and respond to these representations. Translating these representations, in other words, would contribute to decolonization.

In contact zones, Pratt argued, competing worldviews clash with one another. Contact zones are these "social spaces where disparate cultures meet, clash, and grapple with each other, often in highly asymmetrical relations of domination and subordinationsuch as colonialism and slavery, or their aftermaths as they are lived out across the globe today" (ibid., p. 4). The struggle for sovereignty - here expressed as a struggle over the meaning of the past-continues through the present. The struggle is not simply one over meaning, however. Social subjects emerge from the contact in relation to one another, through interactive material, linguistic, and cultural practices.
A "contact" perspective emphasizes how subjects get constituted in and by their relations to each other. It treats the relations among colonizers and colonized... not in terms of separateness, but in terms of co-presence, interaction, interlocking understandings and practices, and often within radically asymmetrical relations of power. (Pratt, 2008, p. 6)

As Pratt frames it, contact zones are not only epistemic, but insofar as subjects are constituted, these zones extend to the ontological realm. Here the paradigm case of contact is translation across social worlds, where these worlds, these social realities, come together, often in conflictual ways. The conflict of the contact is 
highlighted by the opposed set of meanings each side attributes to what is ostensibly the same person or event ("American"). But these sides are unequal and the dominant group tried (tries) to impose its meanings (what "American" means, who is included, and to whom the term belongs). To the extent that the imposition of the dominant hegemony is successful, the subordinate, or subaltern group, may internalize that set of meanings, or-as is in the case above, resist that imposition and fight for their own meanings.

Some time ago, in a well-known essay on British colonial historiography, Ranajit Guha (1988) pointed out this polysemic nature of the sign under colonialism. Influenced by Saussurean structuralism and Barthean semiotics, Guha fashioned a decolonial method of identifying the instability of signs in the colonial context. Under the colonial Raj in India, particular codes engendered a resistant meaning such that "for each of its signs we have an antonym, a counter-message, in another code," Guha explained (ibid, p. 58).

For if the expressions ["peasants," "Islamic puritan," "resistance to oppression," "revolt"] taken together may be said to stand for insurgency, the code which contains all signifiers of the subaltern practice of "turning things upside down" and the consciousness that informs it, then ["insurgents," "fanatic," "wonton atrocities," "disturbing the public tranquil(1)ity"] must stand for its opposite, that is counter-insurgency. The antagonism between the two is irreducible and there is nothing in this to leave room for neutrality. (ibid., p. 59)

One person's terrorist is another person's freedom-fighter, as the old saw has it. On the one side is knowledge-production that fits with imperial rule and the status quo. On the other is subaltern knowledge construction - or its reconstruction, given the epistemic depredations of colonial rule. Guha put the division into binary terms, where the two sides are not equal. He contends that the subaltern account turns dominant meaning upside down.

This implies that the subaltern account is a performative: in order to rebel, the colonized must disrupt not just the sign-system that surrounds the colonized, but the very reality that "defined his very existence."

When a peasant rose in revolt at any time or place under the Raj, he did so necessarily and explicitly in violation of a 
series of codes which defined his very existence as a member of that colonial, and still largely semi-feudal society. For his subalternity was materialized by the structure of property, institutionalized by law, sanctified by religion and made tolerable - and even desirable - by tradition. To rebel was indeed to destroy many of those familiar signs which he had learned to read and manipulate in order to extract a meaning out of the harsh world around him and live with it. (Guha, 1988, p. 41)

The colonial order organizes all of the institutions that surround the colonized. The law, educational institutions, the banking and lending system, television, radio, and print media and so on, inculcate the subaltern with a sense of his or her inferiority. Rebelling requires destroying those signs of his or her inferiority. Thus analysis makes sense not only of how the colonized internalize hegemonic or colonial meanings, but also how colonized people topple those meanings or otherwise displace them.

This point is key for understanding translation and mistranslation across the colonial line, and consequently how colonial (or neo-colonial) translation practices might be studied. Translation practices have played a crucial role in that battle for hegemonic control throughout the colonial world (see, for example, Mignolo,1995,2000; Rafael,1996,2015;Valdeón,2014).Translation has been used as part of domination ever since Augustinian and Franciscan friars translated the bible into indigenous languages of the Americas in the sixteenth century (Price, 2008a). Nineteenth century French colonialists translated Ibn Khaldun in terms of their own racial categories to justify their divide-and-rule racial policies (Hannoum, 2003). English colonialists, and their American descendants, have used interpreters and translators to establish their dominion from Shakespeare's time through the current prosecution of the war on terror (Greenblatt, 1991; Cheyfitz, 1997; Rafael, 2015). The missionary Bernardino de Sahagún (1499-1590) translated massive amounts of knowledge from the vanquished Aztecs' Nahuatl language into Spanish, and, in the other direction, legions of other missionaries translated not only the Gospels, but also the catechism and other Christian teachings and texts into indigenous languages throughout the world for the purpose of evangelizing (see, for example, Lagunas, 2002 [1574]); González Holguín, 1993 [1612]; Valdivia, 1887; León Portilla, 2002; Price, 
2008a). This was a way of imposing a Christian worldview and eschatology on colonized subjects (MacCormack, 1993).

Translation scholars have documented many of the ways in which translators and translation practices have resisted colonization, or at least redirected or channelled colonial power (see, for example, Niranjana, 1992; Rafael, 1996, 2005; Simon and St-Pierre, 2000; Wolf, 2000; Pratt, 2008). The examples below from Douglass and Veloso throw open how the battle for colonial hegemony has resulted in the fragmentation of meaning into dominant and subaltern knowledge.

The fragmentation goes beyond the binary described by Guha, however. Veloso and Douglass use the resources provided by the colonizer but in a way that moves us beyond reducing the power relationship between the dichotomy of colonizer/colonized, master/slave or Western domination/native resistance (Liu, 1995). Instead, we have to ask with Shaden Tageldin, what happens "when a 'native' signifier binds to a 'foreign'-especially a colonizingsignifier to shore up the power of the native through the power of the foreign?" (2011, p. 4) For Douglass and Veloso take up the colonizer's text and their power as a way to explode and neutralize that power. They use colonial discourse and the colonial legacy against itself. As Gayatri Chakravarty Spivak has commented on the subversive strain in Mahasweta Devi's stories (which Spivak has translated), "[t]hey must operate with the resources of a history shaped by colonization against the legacy of colonization" (1995, p. 31). This "deconstructive embrace," as Spivak terms Devi's use of language, "is not only her message, but also her medium" (ibid.).

\section{Methodology}

If the "deconstructive embrace" includes one's "medium," then Spivak provides an opening to analyse translation beyond the text to the full socio-historical context, including all of the paratextual and pragmatic features of a performance. Refraction, wrote André Lefevere several decades ago, is the "adaptation of a work of literature to a different audience, with the intention of influencing the way in which that audience reads the work" (2000 [1982], p. 235). Through insurgent practices of translation, specific acts, gestures, utterances, and so on, find their way to a new, counter-hegemonic audience, a counterpublic (Warner, 2005; Muñoz, 2009; Price, 2012). The meaning of the text, in other words, is linked to those larger social, 
cultural and political contexts. Three interconnected characteristics make the translations decolonial. Taken together, we could call them, adopting Spivak's terminology, a decolonial, deconstructive embrace.

(1) They are abusive (Lewis, 2000; Venuti, 2013).

(2) The target language or culture is an imagined world, better and more just than the world we live in now (Santos, 2014).

(3) They are performatives insofar as they begin to bring that imagined world into existence through performing the translation (Austin, 1975; Robinson, 2014).

As a deconstructive embrace, this kind of translation draws attention to the colonial legacy and to the colonial context, and also to itself-that is, to its own selective appropriation. In this way, the deconstructive gesture can be termed abusive of the original, to paraphrase Philip E. Lewis (2000). Venuti elaborates on the concept of abusive translation.

This kind of translating is abusive in two senses: it resists the structures and discourses of the receiving language and culture, especially the pressure towards the univocal, the idiomatic, the transparent; yet in so doing it also interrogates the structures and discourses of the source text, exposing its often unacknowledged conditions. (Venuti, 2013, p. 72).

Neither Venuti nor Lewis is discussing colonization per se; but the concept of abusive translation fits well within a project of undermining or resisting colonization. An abusive translation can disclose or expose the unacknowledged conditions of imperialism, as well as the racial structures, economic pressures, and even gender system at work in the original utterance or text.

In sum, an abusive translation of this sort defamiliarizes, as the Russian Formalists might say, or draws into view the taken-forgranted cultural, linguistic and material background of colonialism (Shklovsky, 2015 [1919]). But unlike Lewis's account of abusive fidelity, translators who embrace the colonial language only to undermine it are unfaithful - they are traitors to the colonial heritage that their translations reveal. That is to say, they betray rather than uphold the colonial condition. And this should be no surprise, since the colonial condition is a social condition, and each side of the colonial divide is peopled with social and political movements, 
and behind them communities, cultural groups, and even entire societies or regions that face off in unequal relationships of power. Translators inevitably express allegiances as they situate themselves and their translations, even if those allegiances are conflicted, or not quite conscious. An adequate analysis of translation activity in the contact zone of colonialism cannot remain at the level of textual analysis outside of the social conditions that gave rise to them, and the tense sociality of imperialism that provide these translators with audiences ${ }^{2}$. In using translation abusively or deconstructively, these translators, correspondingly, take sides in the battle of interpretation. They steal texts from the winners and infuse them with new meanings in a struggle for hegemonic control, willfully riffing on them, using irony, catachresis, and other rhetorical figures to scuttle dominant sensibilities.

Studying refraction in these cases, one finds the basis for new interpretations by examining how a text has been entextualized in a new or different context (Silverstein and Urban, 1996; Silverstein, 2014).

This brings us to the second characteristic of a decolonial method. The translators translate to an audience in a society that does not yet fully exist; the translation is in the idiom of, and for, a different, better world. What Portuguese scholar Boaventura de Sousa Santos says of critical theory is true of decolonial practices of translation:

A critical theory is premised on the idea that there is no way of knowing the world better than by anticipating a better world. Such anticipation provides both the intellectual instruments to unmask the institutionalized, harmful lies that sustain and legitimate social injustice and the political impulse to struggle against them. Critical theory is therefore meaningless without a search for truth and healing, even if in the end there is no final truth or definitive cure. History shows that the most entrenched social lies have been limited in scope and duration, even if, while in force and dominant, they appear to be the very essence of truth and healing. (Santos, 2014, p. viii)

Decolonial translations are similarly motivated by, and premised in the belief that the world can be a better place. These translations are

2. "Audiences" is the term Lefevere (2000 [1982]) uses when he discusses refraction. 
aspirational insofar as they attempt to translate for a world that is only incipient, a counterpublic (Muñoz, 2009; Price, 2012; Jones, 2013). This is part and parcel of their decolonial contribution: they help bring that de-colonized society or community into existence. This does not mean they exist in a utopian vacuum; quite the contrary, it is within insurgent communities or social movements, partly imagined, partly real, from which they receive their impetus and within which their translations make sense. This is part of the refraction. These social movements or artistic movements are based on a sort of prophetic counterfactual: an imagined future, where things are better. They are situated, then, within an oppositional worldview or perspective but that is not fully realized as an organization of social reality. These worldviews may be unthinkable or unimaginable within the dominant sensibility (Trouillot, 2015).

An abusive translation thus innovates or otherwise makes inroads on the receiving language and culture. It does not necessarily follow established norms of the target language and culture (Hermans, 2002; Price, 2008b). Instead, such a translation,

aims at a radical questioning of the rewarding institution, of the hierarchy of values, beliefs, and representations housed in that institution. This translation-need I say?-is not likely to be received with gratitude, which it does not seek, but it may construct a new intellectual community that did not previously exist. (Venuti, 2013, p. 262)

This sort of abusive translation initiates a "transvaluation" and contributes to constructing new communities, according to Venuti. And this brings me to the third characteristic. These translations are performative insofar as they bring into existence the receiving culture to which they address themselves. The deconstructive work is thus also constructive, as it dismantles existing language and identity in the name of another language, identity, and audience that it helps develop.

As performatives, these translations "perform" a new reality (see also Robinson, 2014). This kind of translation has an ironic quality insofar as its deeper meaning is projected into a different, hopeful future, beyond and beneath and even at odds with the visible present (see Griffiths, 2012). It breaks through ossified meanings to new horizons, with exuberant meanings.

When the Tigres del Norte use irony in this way, they redraw imperial maps. In the sonic sphere of performance, they take 
the listener to the phenomenological sphere of the lived body, located in time and place, a certain kind of subject-racialized as Mexican/Latinx-and project that subject into a different future, when they are no longer treated as strangers in any part of the Americas. In the examples below, Frederick Douglass contributed to building an abolitionist community and Caetano Veloso a new Latin American identity through their deconstructive translations. Sound, performance, and performative translation transforms the racialized colonial subject, previously subject to dispossession, massacre, and exploitation. The silence of the colonial subject of the Americas erupts into voice and song.

\section{"What to the Slave is the Fourth of July?"}

Frederick Douglass provides an opportunity to do just this kind of analysis. He performs an intralingual translation of the Fourth of July, the holiday that marks American (or the United States) Independence from England. In so doing, Douglass deconstructs the meaning of the Fourth of July. He was born a slave in Maryland around 1818 and escaped to the North in 1838 where he began to campaign for an end to slavery. Douglass became an orator and perhaps the nation's highest profile abolitionist. In an antebellum (1852) speech in upstate New York, "What to the Slave is the Fourth of July?", Douglass takes on the subjectivity of the slave and sees a far different reality from the rosy one painted by the Independence Day festivities. "I shall see, this day, and its popular characteristics, from the slave's point of view," (1852, n.p.; see also Colaiaco, 2006) which he contrasts with the point of view of his putatively white audience (whom he addresses as "you"). He then outlines an awful colonial split in meaning,

Your high independence only reveals the immeasurable distance between us. The blessings in which you, this day, rejoice, are not enjoyed in common. - The rich inheritance of justice, liberty, prosperity and independence, bequeathed by your fathers, is shared by you, not by me. The sunlight that brought life and healing to you, has brought stripes and death to me. This Fourth [of] July is yours, not mine. You may rejoice, $I$ must mourn. (Douglass, 1852, n.p.)

Liberty and justice for white America are coextensive with disenfranchisement, institutional debasement, and oppression for black America. This makes for a cruel irony that Douglass, a former slave, uses to challenge his audience: "To drag a man in fetters into 
the grand illuminated temple of liberty, and call upon him to join you in joyous anthems, were inhuman mockery and sacrilegious irony. Do you mean, citizens, to mock me, by asking me to speak to-day?" (ibid.). He speaks from an existential contradiction that implies a pragmatic contradiction: the nation denies his humanity, yet invites him to speak-they are citizens and he is metaphorically in chains. If they wish to hear him, they must grant him his humanity. To deny him humanity yet to ask him to speak is to mock him. This bold rhetorical move does not stop there, as Douglass arrives at the stern conclusion: "Standing, there, identified with the American bondman, making his wrongs mine, I do not hesitate to declare, with all my soul, that the character and conduct of this nation never looked blacker to me than on this 4th of July!"

Translating the significance of the Fourth of July across the colonial divide, Douglass sees the American experiment in democracy as deeply hypocritical. The Fourth of July is just an example. He sets up a further series of contrasts to underscore the nation's duplicity and self-delusion. "You glory in your refinement and your universal education yet you maintain a system as barbarous and dreadful as ever stained the character of a nation":

To [the enslaved], your celebration is a sham; your boasted liberty, an unholy license; your national greatness, swelling vanity; your sounds of rejoicing are empty and heartless; your denunciations of tyrants, brass fronted impudence; your shouts of liberty and equality, hollow mockery; your prayers and hymns, your sermons and thanksgivings, with all your religious parade, and solemnity, are, to him, mere bombast, fraud, deception, impiety, and hypocrisy - a thin veil to cover up crimes which would disgrace a nation of savages. There is not a nation on the earth guilty of practices, more shocking and bloody, than are the people of these United States, at this very hour. (ibid.)

Douglass adroitly organizes a term-for-term translation across the colonial divide, where what is a source of pride on one side signifies humiliation on the other, and so on. He concludes, "for revolting barbarity and shameless hypocrisy, America reigns without a rival."

In taking up the subjectivity of the oppressed, using a decolonial methodology, Douglass violently dislodges meaning, revealing shockingly distinct accounts of social reality. He forces a 
functional change in the sign-system, insisting on an interrogation of the very conditions of freedom, liberty, and independence and what they have meant to those subject to American imperialism and racial domination (Spivak, 1988, p. 3).

Douglass refracts the meaning of liberty and piety into the hidden narrative of violence, chaos, and dehumanization, as well as the bombast, fraud, deception, impiety, and hypocrisy that keeps that narrative hidden. This is because for Douglass, the liberty of white America is predicated on the social death of black people.

He is not alone in this assessment. Douglass' deconstructive embrace takes place alongside a long line of African American thinkers, writers, and-let's call them decolonial interpreters. Solomon Northup, in his now well-known account of his twelve years as a slave, points to the same contradiction. He reflects on the unmistakably American paradox of how the slave pen where he was held after he was kidnapped lay within eyesight of the United States Capitol building. "Strange as it may seem, within plain sight of [the slave pen], looking down from its commanding height upon it, was the Capitol. The voices of patriotic representatives boasting of freedom and equality, and the rattling of the poor slave's chains, almost commingled. A slave pen within the very shadow of the Capitol!" (Northup, 1968 [1853], p. 23) Northup and Douglass see a bitter irony when they speak within an abolitionist sensibility-a thoroughly egalitarian, anti-racist language that had not yet gained the upper hand against the reigning hypocrisy they saw in a society that professed equality and practiced inhumanity. They wrote in an idiom that contravened the reigning commonsense.

Translation at the point of race is presupposed by, and points to, this existential and social split between those constructed as human and those still denied full personhood. I have already described the resulting paradox as they write from the resources of a humanity that is not yet acknowledged. Translation at the point of race reveals and emphasizes the resulting intra-lingual split.

However forcefully Douglass puts forward a subaltern account of Independence Day, he is thus at a disadvantage not only because as a racialized subject, his humanity is in doubt. He presents a set of connotations for the Fourth of July that falls so far outside the mainstream, that seems so harsh, and so completely upended from the prevailing meaning of the holiday as to appear from that dominant, patriotic worldview as hyperbole, even preposterous. 
But this is precisely what is at stake: whose meaning of the Fourth of July will count as the norm? What is a legitimate or illegitimate interpretation is always under negotiation, always being contested. In other words, a struggle for hegemony is always underway to establish which account or set of associations are central and which are marginal. Some accounts of the world, and some ways of studying it, are recognized in the dominant culture as credible, reasonable. They are consistent with a normative view of the world, the society, its institutions, its morality, its legal system, the forms of logic and argumentation it uses. Others are dismissed as idiosyncratic, paranoid, or outrageous.

The Fourth of July serves as an exemplary case of colonial intralingual translation in part because of Douglass' acuity, but the examples could be multiplied. Although few today would be so bold as Douglass in denouncing the Fourth of July (though his speech is one of the most famous in the history of American oratory), many Americans refuse to celebrate American Thanksgiving or Columbus Day, days of pride and festivity within the dominant mainstream, but that stand as symbols of colonial settler hypocrisy and rapaciousness for indigenous peoples and their supporters.

This is the counterpublic for whom Douglass translates in a society that was deeply divided then and is deeply divided now (Buzelin, 2005). He refracts the meaning of the Fourth of July to articulate this basic contradiction in American democracy.

We arrive at this conclusion through an analysis of colonial refraction. "Suppose we concede that the strength of translation lies in its abuses - in the productive difference consisting in that twist or skewing signaled by the prefix ab that is attached to the dominant $\mathrm{c}(\mathrm{h})$ ord of use," Lewis wondered, "how far can the abuse be carried?" (2000, p. 226) Douglass gives us one answer to this question. The abuse can reveal the social scaffolding of racism that girds the society but that is also destroying it. "Capturing the 'shimmering' quality of incompatible realities that are true simultaneously requires juxtaposing multiple accounts, taking up one while not entirely letting go of another" (Coutin, 2007, p. 6). Frederick Douglass shows us those comingling, incompatible realities that hinge on the meaning of a single holiday.

\section{Minha América!}

This same decolonial methodology can be used to analyze "transmodern" (Dussel, 2002) translations. 
Modernity's recent impact on the planet's multiple cultures ... produced a varied "reply" by all of them to the modern "challenge." Renewed, they are now erupting on a cultural horizon "beyond" modernity. I call the reality of that fertile multicultural moment "trans"-modernity. (Dussel, 2002, p. 221)

An example of a "trans"-modern reply is provided by singer Caetano Veloso's recording of Augusto de Campos' Brazilian Portuguese translation (1986) of one of John Donne's Elegies (1654). Much has been written on brothers Augusto and Haroldo de Campos' anthropophagic approach to translation (see, for example, Viera, 1994, 2012; Veloso, 2003; de Campos, 2007; Gentzler, 2008). Influenced by Oswald de Andrade's modernist "Cannibal Manifesto," Haroldo de Campos famously argued that the (Brazilian) translator can be a "bad savage" who devours whites, and is "capable of appropriation and of expropriation, of dehierarchization, of deconstruction. Any past which is an 'other' for us deserves to be negated. We could even say, it deserves to be eaten, devoured" (Campos, 2007, pp. 159-160). But de Campos added an important proviso: the cannibal "devoured only the enemies he considered courageous, taking their marrow and protein to fortify and renew his own natural energies" (ibid., p. 160).

A self-conscious inheritor of this cannibalistic approach to world cultures, Veloso is one of Latin America's most prominent contributors to popular music and a brilliant composer. He has described his political and philosophical anthropophagic formation in great depth (Veloso, 2003; see also Veloso and Dunn, 1996; Dunn, 2001); indeed, on an early album cover Veloso posed along with Gilberto Gil and others from the Tropicália movement (which he helped found) holding a picture-portrait of Oswald de Andrade, the avant-garde poet and critic who initiated the modernist idea of Brazilian cannibalism (Tropicália ou Panis et Circencis, 1968).

Since its beginnings, the Tropicália movement has been characterized by an omnivorous hunger-consuming an eclectic assortment of music and texts, mixing high and low art, East and West (see, for example, Lee, 2006). Veloso has drawn a vivid picture of how their music borrowings shifted their "being-in-the-world." As he put it,

By using electric guitar in melodic compositions with elements of Argentine tango and African things from 
Bahia, we assumed an immediate posture of "being-inthe-world"-we rejected the role of a Third World country living in the shadow of more developed countries. Through our art we wanted to put forward a vision of the world at that time, from our own perspective as Brazilians. (Veloso and Dunn, 1996, p. 121)

True to their anthropophagic roots, the Tropicália musicians assert and fortify their Brazilianness, rather than dilute it, through ingesting the foreign. Veloso has characterized this tendency in Tropicália as an "aggressive nationalism," characterized by a cosmopolitanism that consumes these imported cultural products, in contrast to a narrow, "defensive" nationalism that is always trying to stave off the foreign (Veloso and Dunn, 1996, p. 118). If we take Veloso at his word, the "Brazilian perspective" has been simultaneously an existential or ontological condition; this is why he uses the phrase "being-in-the-world."

Caetano Veloso's recording of de Campos' translation of John Donne's original "Elegy 19: To His Mistress Going To Bed" adds a resolutely Brazilian and Latin American tone to Donne. Veloso moreover crafts his performance in ways that make the recording singular and irreducible to the published, written translation by de Campos (1986). He thereby contributes to constituting and reconstituting the Americas in a way I am linking to the decolonial method described above.

In order to understand what Veloso does in his performance, first we need to understand John Donne's original text. In his playfully erotic poem, Donne beckons his lover and urges her to disrobe. Then, upon taking her in, he likens his lover's body to America ("O my America!"), which the poet discovers and makes part of his kingdom when he lands upon it. "My Empirie," he exclaims ecstatically, "How blest am I in this discovering thee." Augusto de Campos preserves this subject/object relation in his translation (1986). ${ }^{3}$ On his album Cinema transcendental (1979), Veloso recorded a fragment of Augusto de Campos' translation of the poem, put to music by Péricles Cavalcanti. Veloso cunningly excerpted only a small section of the poem, and thereby managed to reverse the metaphor: if Donne friskily likens his mistress to the newly discovered lands of the new world, in Veloso's version the

3. Gentzler (2008, p. 101) misattributes this translation to Caetano Veloso. This is worth noting since Gentzler's text is ostensibly about this translation. 
American continent becomes as intimate as a lover: Veloso's elegy is a love song to a continent.

Licence my roving hands, and let them go,

Before, behind, between, above, below.

O my America! my new-found-land,

My kingdom, safeliest when with one man mann'd,

My Mine of precious stones, My

Empirie,

How blest am I in this discovering thee!

To enter in these bonds, is to be free;

Then where my hand is set, my seal shall be.

Full nakedness! All joys are due to thee,

As souls unbodied,

(John Donne, 1654,n.p.)
Deixa que a minha mão errante adentre

Atrás, na frente, em cima, em baixo, entre.

Minha América! Minha terra à vista,

Reino de paz, se um homem só a conquista,

Minha Mina preciosa, meu Império!

Feliz de quem penetre o teu mistério

Liberto-me ficando teu escravo;

Onde cai minha mão, meu selo gravo.

Nudez total! Todo prazer provém

De um corpo (como a alma sem corpo)

(Augusto de Campos, 1986, p. 55)

Donne's poem is about his glee watching his mistress undressing. It is a mischievous romp where the patriarchal (and emphatically heterosexual) eye merges with the colonial eye: America is a conceit for a lyric on the plenitude of his mistress's body. The feminized object of lust, his mistress/America, is not given a speaking part. In Caetano Veloso's hands, "Elegia" whimsically paints a sensual América. Silent in the original poem, in the translation the continent answers back to Donne. Veloso takes palpable pleasure in the continent that created him; he is of the Americas, he is singing a love song that is at the same time an exercise of selfinvention. ${ }^{4}$ Objectification in Donne is traded in for self-making to paraphrase Daphne Brooks in another context (Brooks, 2006, pp. 2-3).

4. Caetano Veloso has sung alongside Mercedes Sosa and many others in a bid to unify a Latin American progressive movement against the military regimes that had forced both into exile. 
An earlier reader of this essay commented that the original and the translation have much in common. Superficially, they do, as de Campos' translation renders Donne exquisitely. But focusing on equivalence and similarity overlooks the ironic inversion in the performance. Veloso literally changes the subject and object of the poem: he subversively shifts the deictic "I" and "you" to transform the sexual and even racial meaning entirely. Donne's mistress, that alienated and mute love-object, is translated into self-actualizing performance as Veloso's continent becomes animate. This is characteristic of how Tropicália "disrupts the dichotomous views of source and target," as Else Viera has put it, "and advances the role of the receiver as a giver in its own right, further pluralizing (in) fidelity" (Viera, 2012, p. 95).

The inversion is deliberate, self-conscious and informed by the (post)modernist cannibalistic tradition of Tropicália (Dunn, 2001; Veloso, 2003). That this gesture of inversion is self-conscious becomes obvious once one looks at the aesthetics of the Tropicália movement, as reflected in, for example, the enormous oeuvre of Veloso's recordings of his own compositions and his versions of popular music from throughout the Americas.

He has been clear about the new existential and erotic possibilities of Tropicália's musical experimentation to rethink national and hemispheric identities. "Elegia," for example, is echoed by other music in Veloso's repertoire, including the betterknown "Soy Loco Por Ti, América," "I am crazy for you, América," composed by Gilberto Gil, Torquato Neto, and José Carlos Capinan). This latter song, which Veloso made famous, is also a paean to the Americas. With lyrics in a mixture of non-standard Spanish and Portuguese, it alludes to José Martí in the first stanza and by implication his Nuestra América (Our America), Martís polemic for a unified Latin America against, among other things, the depredations of both colonial Spain and the United States. ${ }^{5}$

Veloso goes further than simplify reacting against Donne's metaphor of a feminized and sexualized America or even defanging that metaphor through ludic reversal. His version exhibits a hardearned love for Donne's imagery as a source of Brazilian affirmative

5. Christopher Dunn has suggested that this song shares affinities with protest music in how it invokes Che Guevara ("el hombre muerto") as part of the symbology of the revolutionary struggle to unite Latin America (2001, p. 119). 
identity. Veloso has expounded on this cannibalistic technique that he and others in the movement have used over the decades:

A trend we were exploring in Tropicalism: that is, to take an object - a vulgar, even a culturally repulsive object-and remove it from its context, displace it. For example, you want to bring in an object that's culturally repulsive, so you go embrace it and then you dislocate it. Then you start to realize why you chose that particular object, you begin to understand it, and you realize the beauty in the object, and the tragedy involved in its relationship with humanityhumanity's tragedy for creating that object and that kind of relationship - and finally you start to love it. And if there really is something lovable about it, you begin to respect it. (Veloso in Veloso and Dunn, 1996, p. 132)

Veloso is referring here to a much-criticized stereotypical image of Brazil, exemplified in Carmen Miranda's Hollywood films. He wanted to neutralize the power of the colonial caricature by incorporating it into his repertoire. In his philosophical treatise/ memoir Verdade Tropical ("Tropical Truth”) (1997), Veloso explicitly acknowledged the importance of Carmen Miranda, including her sexuality, which served as a potent reference and inspiration for travestis, as well as queer and androgynous themes in Tropicália (Veloso, 1997, pp. 268-269).

In the case at hand, Veloso similarly takes up the frank sexuality and erotic possibilities of Donne's poem and weaves them into his plunge into América. It may seem odd that an avant-gardist like Caetano Veloso would appropriate a poem from seventeenth century England for cultural renewal and sustenance. In reflecting on the trajectory of Tropicalismo, Veloso remarked in an interview in the 1990s on their aesthetics of pastiche. "We did something similar to what the pop artists in the U.S.A were doing in the visual arts: we took what was kitsch - what was considered bad taste and we placed it in a more sophisticated repertoire." (Veloso in Veloso and Dunn, 1996, p. 121). Donne's poetry is in no way kitsch, but Veloso is making a larger point that applies here as well: "This dislocation was a vital and characteristic practice of the 1960s. And for Brazil that dislocation was full of implications" (ibid.)

As a goal for translation, dislocating and displacing Donne, recuperating the repellent literary trope, revalorizing and resignifying images of colonial sexual debasement and making them 
cool and self-affirming, takes us beyond a traditional framework of understanding anti-colonial activity within a paradigm that is predicated on a binary; viz., native resistance to foreign domination.

Placing Veloso's translation contrapuntally to Donne's, to use Edward Said's term, throws into relief the poetics of imperialism in one and the deconstructive postcolonial riposte of the other (Said, 1993, pp. 66-67; see also Cheyfitz, 1997). The contraposition defamiliarizes both (Shklovsky, 2015 [1919]). It draws our attention to the contrasting elements that might otherwise go by as unremarkable. Put differently, through the contrast, we can see how Veloso's performance acts as a form of criticism and critique of the original (Gaddis Rose, 1998). The new version sets out the terms for a new Latin American, or Américan (with an accent) identity.

An elegy is a lament for the dead. In this elegy, however, Veloso announces the birth of a new sensual space, an erotic future for the Americas (Muñoz, 2009; Jones, 2013); taking into consideration his recordings not just in Portuguese but in Spanish and English, with even a smattering of Guaraní and other indigenous languages, Veloso's América is an inclusive, multilingual, heterodox space of engagement and invention.

\section{Conclusion: Gulfs and Dissonances}

Douglass and Veloso refract "America" to a new, imagined audience that they help bring into being through their hopeful translations. Their songs and speeches reverberate backward and forward in time - back through settler colonial history, back to the Treaty of Guadalupe Hidalgo, back to Amerigo Vespucci. Back, back, back. And forward to limn a future that we can trace in the present, a future when undocumented people, the enslaved, and all who live in the Americas will have full civil and social status. "America never was America to me/And yet I swear this oath -America will be!" promises Langston Hughes (2016 [1935], n.p.). These performative translations imply a future that imbues "America" with new significance.

Somos todos americanos/We are all American could serve as the line that connects Frederick Douglass to Caetano Veloso and Los Tigres. Each translates imperial terms into an exuberant vision of what it is to be human in the Americas against a source language that degrades and dehumanizes. These exuberant translations 
cannot be easily reconciled to the restrictive, settler notions of who counts as an American. What counts as memory, history, identity, what is reasonable and what is outlandish, what is honest and dishonest is at odds on either side of the divide.

The discrepancy in meaning, then, implies a discrepancy in power. The meaning that comes to be definitive and names the event, so to speak, is contingent on such factors as institutional and structural backing, authority, legitimacy, social uptake. A decolonial methodology of translation allows-or demands-that we negotiate the interests and the investments different actors have in different meanings. The authoritative account has credibility conferred upon it. So this investigation also requires a sociology of knowledge: who confers that credibility, under what circumstances or conditions, and with what social implications.

A decolonial methodology dislocates a monolithic, colonial inhabitation of the world that depends on evading subaltern perceptions and interpretations, and that has plied us with so many illusions.

\section{References}

Austin, J.L.A. (1975). How to Do Things with Words. Cambridge [MA], Harvard University Press.

Brooks, Daphne A. (2006). Bodies in Dissent: Spectacular Performances of Race and Freedom, 1850-1910. Durham [NC], Duke University Press.

Buzelin, Hélène (2005). "Unexpected Allies: How Latour's Network Theory Could Complement Bourdieusian Analyses in Translation Studies." The Translator, 11, 2, pp. 193-218.

Cheyfitz, Eric (1997). The Poetics of Imperialism: Translation and Colonization from The Tempest to Tarzan. Philadelphia, University of Pennsylvania Press.

Colaiaco, James A. (2006). Frederick Douglass and the Fourth of July. New York, Palgrave Macmillan.

Costa, Claudia de Lima (2014). "Introduction to the Debates about Translation: Lost (and Found?) in Translation: Feminisms in Hemispheric Dialogue.” In S. E. Alvarez et al., eds. Translocalities Translocalidades: Feminist Politics of Translation in the Latin/a Américas. Durham [NC], Duke University Press.

Coutin, Susan (2007). Nation of Emigrants: Shifting Boundaries of Citizenship in El Salvador and the United States. Ithaca [NY], Cornell University Press. 
De Campos, Augusto (1986). "Elegia: indo para o leito." O anticristo. Brazil, Companhia das Letras.

De Campos, Haroldo (2007) [1981]. "Anthropophagous Reason: Dialogue and Difference in Brazilian Culture." In A. S. Bessa, ed. Novas. Trans. Odile Cisneros. Chicago, Northwestern University Press.

Donne, John (1654). “Elegy 19: To His Mistress Going To Bed.” [http:// www.poetryfoundation.org/poem/180683].

Douglass, Frederick (1852). "What to the Slave Is the Fourth of July?" [http://teachingamericanhistory.org/library/document/what-tothe-slave-is-the-fourth-of-july/].

Dunn, Christopher (2001). Brutality Garden: Tropicália and the Emergence of a Brazilian Counterculture. Durham [NC], University of North Carolina Press.

Dussel, Enrique D. (2002). "World-System and "Trans"-Modernity." Trans. Allesandro Fornazzari. Nepantla: Views from the South, 3, 2, pp. 221-244.

Gaddis Rose, Marilyn (1998). Translation and Literary Criticism. New York, Routledge.

Gentzler, Edwin (2008). Translation and Identity in the Americas: New Directions in Translation Theory. London and New York, Routledge.

González Holguín, Diego (1993 [1612]). Vocabulario de la lengua general de todo el Perú llamada lengua qqichua o del Inca y en la lengua Española. El Mas Copioso Y Elegante, que hasta agora se ha impresso. Quito, Proyecto Educación Bilingüe Intercultural; Corporación Editora Nacional.

Greenblatt, Stephen (1991). Marvelous Possessions: The Wonder of the New World. Chicago, University of Chicago.

Griffiths, Paul J. (2012). “Called to a Halt.” Review of J. Lear's A Case for Irony. Commonweal, 9 March, pp. 22-23.

Guha, Ranajit (1988). "The Prose of Counter-Insurgency.” In R. Guha and G. Spivak, eds. Selected Subaltern Studies. New York, Oxford University Press.

Hannoum, Abdelmajid (2003). "Translation and the Colonial Imaginary: Ibn Khaldûn Orientalist." History and Theory, 42, 1, pp. 61-81.

Hermans, Theo (2002). "The Production and Reproduction of Translation: System Theory and Historical Context." In S. Paker, ed. Translations: (Re)shaping of Literature and Culture. Istanbul, Bogaziçi University Press, pp.175-94.

Hughes, Langston (2016 [1935]). "Let America Be America Again." [https://www.poets.org/poetsorg/poem/let-america-be-americaagain]. 
Jones, Angela, ed. (2013). A Critical Inquiry into Queer Utopias. New York, Palgrave Macmillan.

Lagunas, Juan Baptista de (2002 [1574]). Arte en lengua michuacana. Transcription by Agustín Jacinto Zavala. Zamora, Michoacán, Colegio de Michoacán; México, D.F., Fideicomiso Teixidor.

Lee, Rita (2006). Aqui, Ali, Em Qualquer Lugar. [Audio CD]. Brazil, Deckdisk Music.

Lefevere, André (2000 [1982]). "Mother Courage's Cucumbers: Text, System and Refraction in a Theory of Literature." In L. Venuti, ed. The Translation Studies Reader. New York, Routledge.

León Portilla, Miguel (2002). Bernardino de Sahagún, First Anthropologist. Trans. Mauricio J. Mixto. Oklahoma, University of Oklahoma Press. Lewis, Philip E. (2000). “The Measure of Translation Effects." In L. Venuti, ed. The Translation Studies Reader. New York, Routledge.

Liu, Lydia (1995). Translingual Practice: Literature, National Culture, and Translated Modernity-China 1900-1937. Stanford [CA], Stanford University Press.

Los Tigres Del Norte (2006). "Somos más americanos." In Uniendo Fronteras. [Audio CD]. California, Fonovisa.

MacCormack, Sabine (1993). "Demons, Imagination, and the Incas." In S. Greenblatt, ed. New World Encounters. Berkeley, University of California Press.

Mignolo, Walter D. (1995). The Darker Side of the Renaissance: Literacy, Territoriality, and Colonization. Ann Arbor, University of Michigan Press.

Mignolo, Walter D. (2000). Local Histories/Global Designs: Coloniality, Subaltern Knowledges and Border Thinking. Princeton, Princeton University Press.

Muñoz, José Esteban (2009). Cruising Utopia: The Then and There of Queer Futurity. New York, New York University Press.

Niranjana,Tejaswini(1992). Siting Translation: History, Post-Structuralism, and the Colonial Context. Berkeley, University of California Press.

Northup, Solomon (1968 [1853]). Twelve Years as a Slave. S. Eakin and J. Logsdon, eds. Baton Rouge, Louisiana State University Press.

Pratt, Mary Louise (2008). Imperial Eyes: Travel Writing and Transculturation. New York, Routledge.

Price, Joshua M. (2008a). "Hidden Asymmetries: The Role of Bilingual Dictionaries in Spanish Colonialism in the Sixteenth and Seventeenth Centuries." In A. Benessaieh, ed. Canada and the Americas: Multidisciplinary Perspectives on Transculturality. Toronto, Antares, pp. 131-142. 
Price, Joshua M. (2008b). “Translating Social Science: Good versus Bad Utopianism." Target, 20, 2, pp. 348-364.

Price, Joshua M. (2012). Structural Violence: Hidden Brutality in the Lives of Women. Albany [NY], State University of New York Press.

Rafael, Vicente L. (1996). Contracting Colonialism: Translation and Christian Conversion in Tagalog Society Under Early Spanish Rule. Durham [NC], Duke University Press.

Rafael, Vicente L. (2005). The Promise of the Foreign: Nationalism and the Technics of Translation in the Spanish Philippines. Durham [NC], Duke University Press.

Rafael, Vicente L. (2015) "Betraying Empire: Translation and the Ideology of Conquest." Translation Studies, 8, 1, pp. 82-93.

Robinson, Douglas (2014). Performative Linguistics: Speaking and Translating as Doing Things with Words. New York, Routledge.

Said, Edward (1993). Culture and Imperialism. New York, Vintage Books. Santos, Boaventura de Sousa (2014). Epistemologies of the South: Justice Against Epistemicide. Boulder and London, Paradigm Publishers.

Shklovsky, Viktor (2015 [1919]). “Art, as Device.” Trans. Alexandra Berlina. Poetics Today, 36, 3, pp.151-174.

Silverstein, Michael (2014). "The Voice of Jacob: Entextualization, Contextualization, and Identity." English Literary History, 81, 2, pp. 483-520.

Silverstein, Michael and Greg Urban (1996). "The Natural History of Discourse.” In M. Silverstein and G. Urban, eds. Natural Histories of Discourse. Chicago, University of Chicago Press.

Simon, Sherry and Paul St-Pierre, eds. (2000). Changing the Terms: Translating in the Postcolonial Era. Ottawa, University of Ottawa Press.

Spivak, Gayatri Chakravorty (1988). "Subaltern Studies: Deconstructing Historiography." In R. Guha and G. C. Spivak, eds. Selected Subaltern Studies. New York, Oxford University Press, pp. 3-32.

Spivak, Gayatri Chakravarty (1995). “Translator's Note.” Imaginary Maps: Three Stories by Mahasweta Devi. New York, Routledge.

Tageldin, Shaden M. (2011). Disarming Words: Empire and the Seductions of Translation in Egypt. Berkeley, University of California Press.

Tropicália ou Panis et Circencis (1968). Various. Brazil, Philips.

Trouillot, Michel-Rolph (2015). Silencing the Past: Power and the Production of History. New York, Beacon.

Valdeón, Roberto (2014). Translation and the Spanish Empire in the Americas. Amsterdam/Philadelphia, John Benjamins.

Valdivia, Luis de (1887). Arte, vocabulario y confesionario de la lengua de 
Chile. Leipzig, J. Platzmann, B.G. Teubner.

Veloso, Caetano (1968). "Soy Loco Por Tí América." Caetano Veloso. Composed by Torquato Neto, Gilberto Gil e Capinan. Brazil, Philips. Veloso, Caetano (1979). "Elegia." Cinema transcendental. [Audio CD]. Brazil, Universal Music.

Veloso, Caetano (1997). Verdade Tropical. São Paulo, Brazil, Companhia das Letras.

Veloso, Caetano (2003). Tropical Truth: A Story of Music and Revolution in Brazil. Trans. Barbara Einzig and Isabel de Sena. Boston, Da Capo Press.

Veloso, Caetano and Christopher Dunn (1996). "The Tropicalista Rebellion." Trans. by Andrea Kouklanakis. Transition, 70, pp. 116138.

Venuti, Lawrence (2013). "Translating Derrida on Translation: Relevance and Disciplinary Resistance.” Translation Changes Everything: Theory and Practice. New York, Routledge, pp. 57-79.

Viera,Else R.P.(1994)."A Postmodern Translational Aesthetics in Brazil.” In M. Snell-Hornby, F. Pöchhacker and K. Kaindl, eds. Translation Studies: An Interdiscipline. Selected papers from the Translation Studies Congress, Vienna, 1992. Amsterdam/Philadelphia, John Benjamins, pp. 65-72.

Viera, Else R.P. (2012). "Liberating Calibans: Readings of Antropofagia and Haroldo de Campos' Poetics of Transcreation." In S. Bassnett and H. Trivedi, eds. Postcolonial Translation: Theory and Practice. New York, Routledge, pp. 95-113.

Wallerstein, Immanuel (1981). "Concepts in the Social Sciences: Problems of Translation." In M. Gaddis Rose, ed. Translation Spectrum: Essays in Theory and Practice. Albany, State University of New York Press, pp. 88-98.

Warner, Michael (2005). Publics and Counterpublics. New York, Zone Books.

Wolf, Michaela (2000). “The Third Space in Postcolonial Representation.” In S. Simon and P. St-Pierre, eds. Changing the Terms: Translating in the Postcolonial Era. Ottawa, University of Ottawa Press, pp. 127-146.

Joshua M. Price Department of Sociology Binghamton University Binghamton, NY 13902 UNITED STATES jmprice@binghamton.edu 